\title{
ANALYSIS OF THE FACTORS THAT INFLUENCE STUDENTS' LEVEL OF FINANCIAL LITERACY
}

\section{ANALISIS FAKTOR-FAKTOR YANG MEMENGARUHI TINGKAT LITERASI KEUANGAN MAHASISWA}

\author{
Oleh: \\ Mutiarasari Dewi Radityas \\ Accounting Education Study Program Yogyakarta State University \\ mutiaradityas@gmail.com \\ Adeng Pustikaningsih \\ Lecturer of Accounting Education Department Yogyakarta State University
}

\begin{abstract}
This study aimed to know the influence of Gender, GPA, Year of Study, Residence, Parent's Education Level (Father), Parent's Education Level (Mother), Parent's Income Level, and Work Experience on the Level of Financial Literacy Students of Accounting Education Faculty of Economics YSU 20152017. The validity of the instrument used the Product Moment Correlation and instrument reliability using Cronbach Alpha. The data analysis technique used was ordinal logistic regression analysis. The results of this study showed that 1) Gender does not influenced Students' Level of Financial Literacy; 2) GPA influenced Students' Level of Financial Literacy; 3) Year of Study influenced Students' Level of Financial Literacy; 4) Residence does not influenced Students' Level of Financial Literacy; 5) Parent's Education Level (Father) does not influenced Students' Level of Financial Literacy; 6) Parent's Education Level (Mother) influenced Students' Level of Financial Literacy; 7) Parent's Income Level does not influenced Students' Level of Financial Literacy; 8) Work Experience influenced Students' Level of Financial Literacy.
\end{abstract}

Keywords: Gender, GPA, Year of Study, Residence, Parent's Education Level, Parent's Income Level, Work Experience, The Level of Financial Literacy

\begin{abstract}
Abstrak
Penelitian ini bertujuan untuk mengetahui pengaruh Gender, IPK, Tahun Angkatan, Tempat Tinggal, Tingkat Pendidikan Orang Tua (Ayah), Tingkat Pendidikan Orang Tua (Ibu), Tingkat Pendapatan Orang Tua, dan Pengalaman Bekerja terhadap Tingkat Literasi Keuangan Mahasiswa Pendidikan Akuntansi FE UNY Tahun Angkatan 2015-2017. Validitas instrumen menggunakan Product Moment Correlation dan reliabilitas instrumen menggunakan Cronbach Alpha. Teknik analisis data yang digunakan adalah analisis regresi logistik ordinal. Hasil penelitian ini adalah menunjukkan bahwa variabel 1) Gender tidak berpengaruh terhadap Tingkat Literasi Keuangan Mahasiswa; 2) IPK berpengaruh terhadap Tingkat Literasi Keuangan Mahasiswa; 3) Tahun Angkatan berpengaruh terhadap Tingkat Literasi Keuangan Mahasiswa; 4) Tempat Tinggal tidak berpengaruh terhadap Tingkat Literasi Keuangan Mahasiswa; 5) Tingkat Pendidikan Orang Tua (Ayah) tidak berpengaruh terhadap Tingkat Literasi Keuangan Mahasiswa; 6) Tingkat Pendidikan Orang Tua (Ibu) berpengaruh terhadap Tingkat Literasi Keuangan Mahasiswa; 7) Tingkat Pendapatan Orang Tua tidak berpengaruh terhadap Tingkat Literasi Keuangan Mahasiswa; 8) Pengalaman Bekerja berpengaruh terhadap Tingkat Literasi Keuangan Mahasiswa.
\end{abstract}

Kata kunci : Gender, IPK, Tahun Angkatan, Tempat Tinggal, Tingkat Pendidikan Orang Tua, Tingkat Pendapatan Orang Tua, Pengalaman Bekerja, Tingkat Literasi Keuangan 


\section{INTRODUCTION}

Financial literacy is a basic need in the form of knowledge and the ability to manage personal finance to make the right decisions in finance to avoid financial problems. Financial literacy can also be defined as the ability to make informed judgments and effective decision making regarding the use and management of money.

Based on the results of the National Survey of Indonesian Financial Literacy by Otoritas Jasa Keuangan (OJK) in 2016, it is known that Indonesia's financial literacy index is $29.7 \%$. This means that out of 100 people only about 29 people were included in the category of well literate. Well literate means having the knowledge and confidence about financial services and financial service products, including features, benefits and risks, rights and responsibilities of related financial products and services, as well as having skills in the use of financial products and services. This condition illustrates that Indonesian people do not yet have enough knowledge of how to optimize money for productive activities. Besides, people also have not understood well the various financial products and services offered by formal financial services institutions and more interested in other investment offerings that could potentially harm them.

The level of financial literacy is categorized into three groups, namely 1) below $60 \%$ which means represents a relatively low-level knowledge of finance, 2) $60 \%$ to $80 \%$ represents a medium level knowledge of finance, and 3) more than $80 \%$ represents a high financial understanding of finance. This categorization is based on the results of research on student financial literacy conducted by Chen and Volpe (1998) on 924 students from 13 universities in various countries. Based on that category, the level of financial literacy in Indonesia is at a low level. This figure is lower if compared with other countries. Data obtained by Visa (2012) on Visa's International Financial Literacy Barometer of 2012, it is known that the level of financial literacy Indonesia is in the two lowest positions of 28 countries, which amounted to $27.7 \%$. Based on that survey it was found that only $18,2 \%$ of the population in Indonesian society could endure a personal economic emergency lasting more than three months. Besides that the awareness of Indonesian people to have a financial budget so that their personal financial are more controlled and avoid financial problems also still low. It was only $35,1 \%$ of the population who have and follows their financial budget.

In January up to May 2018, OJK has been cracking down on 76 entities suspected to have operated without permission and potentially harming the public. The number of entities that dealt with this year expected to rise compared to 2017 which reached 102 entities. This investment fraud cases are found namely fraud multilevel marketing (MLM), cryptocurrency, and cases of illegal investment. This could either be an illegal investment activity that did not have a permit or have permission, but its operations are not under such license.

College students are one of the components of society that the number is large enough and give influence to the economy because in the future students will work and start independent including in financial management. Therefore, students should be given knowledge of managing finances. Students are also expected to improve their understanding of the financial services sector to be able to manage finances well and can realize a prosperous Indonesian society. In this case, OJK has launched the Financial Literacy Series for College Students as a form of implementation of National Survey of Indonesian Financial Literacy which is one of the pillars mandating the implementation of education and national financial literacy campaigns.

Accounting Education is one of the majors as well as study program at Yogyakarta State University (YSU). Students of Accounting Education are 
candidates of educational degree who obtain materials on education, accounting, and economics. Some of the lecture materials obtained are Introduction to Accounting, Intermediate Financial Accounting, Advanced Financial Accounting, Introduction to Management, Financial Management, Basics of Economics, and educational materials such as Teacher Profession Ethics, Education Management, Curriculum and Accounting Learning, and Assessment of Accounting Learning. By obtaining learning about these materials then Accounting Education students should have a good level of financial literacy.

Based on a preliminary survey of questionnaires conducted on 1-3 June 2018 on financial literacy students of Accounting Education Faculty of Economics YSU year of study 2015 to 2017 , resulted in 78 students who filled out a questionnaire shows the level of financial literacy with a percentage of $55.95 \%$. Based on the categorization of the level of financial literacy by Chen and Volpe (1998), it is known that the level of financial literacy of students of Accounting Education Faculty of Economics YSU 2015-2017 is in a low category. However, the result of the survey is not enough to describe the condition of financial literacy of Accounting Education Student Faculty of Economics YSU year of study 2015-2017 as a whole. Besides, it is not yet known what factors influence the level of student's financial literacy.

The level of financial literacy is influenced by several factors. According to Chen and Volpe (1998: 114-121) the factors affecting financial literacy are educational background (academic disciplines and class rank), demographic characteristics (gender, race, nationality), and work experience. While according to Ansong and Gyensare (2012: 126-133) the factors which affect the level of financial literacy namely age, work experience, majors, and mother's level of education. According to Nababan and Sadalia (2012: 1-15) factors that affect financial literacy are gender, study programs, year of study, GPA, residence, parent's education level, and parent's income level. Factors influencing financial literacy according to Krishna, Rofaida, \& Sari (2010: 552-600) are gender, age, study program origin, and work experience. Margaretha and Pambudhi (2015: 76-85) stated the factors that affect financial literacy, namely gender, GPA, and parent income. It can be concluded that in general the factors influencing financial literacy are Gender, GPA, Year of Study, Residence, Parent's Education Level (Father and Mother), Parent's Income Level, and Work Experience.

This research aimed to know the influence of Gender on the Level of Student Financial Literacy, GPA on the Level of Student Financial Literacy, Year of Study on the Level of Student Financial Literacy, Residence on the Level of Student Financial Literacy, Parent's Education Level (Father) on the Level of Student Financial Literacy, Parent's Education Level (Mother) on the Level of Student Financial Literacy, Parent's Income Level on the Level of Student Financial Literacy, and Work Experience on the Level of Financial Literacy Students of Accounting Education Faculty of Economics YSU 2015-2017.

The benefits of this research include the theoretical benefits and the practical benefits. The theoretical benefits of this research is expected to contribute to the development of science and enrich the treasury of research on financial literacy so that it can be used as reference material for further researchers in the same study but on a wider scope and depth. The practical benefit of this research are to gain insight and knowledge related to the problems studied and answer the questions of researchers about the factors that influence the Level of Financial Literacy students of Accounting Education Faculty of Economics YSU 2015-2017; expected to be useful for students of Accounting Education 
Faculty of Economics YSU 2015-2017 in deepening knowledge, skill, and ability in financial literacy; expected to manage their finance in short and long-term; and expected to be useful as a reading material and reference to increase insight about the Factors that influence the Level of Financial Literacy Students of Accounting Education Faculty of Economics YSU 2015-2017.

\section{RESEARCH METHODS}

\section{Types of Research}

This research used a quantitative approach, that is by using data using research instrument, data analysis is a quantitative/statistic with a purpose for the hypothesis which has been determined. Quantitative data is data in the form of numbers or qualitative data that is inclined or scoring (Sugiyono, 2015: 23). This study includes a type of comparative causal research. Comparative causal research is a type of research in which research is conducted to determine or factors that exist in the behavior or status of groups or individuals (Darmadi, 2013: 171).

\section{Time and Place of The Research}

This research was conducted at the Faculty of Economics, Yogyakarta State University which is located in Karangmalang Caturtunggal Depok Sleman Daerah Istimewa Yogyakarta. This research was done in June - September 2018.

\section{Population and Sample of The Research}

A population is the whole object of research (Arikunto, 2014: 173). According to Sugiyono (2015: 117) population is a generalization region consisting of objects or subjects that have certain qualities and characteristics set by researchers to be studied and then drawn conclusions. Population in this research is Student of Accounting Education Faculty of Economics YSU Year of Study 2015-2017 number of 221 students.
Table 1. Distribution Number of Students of Accounting Education Faculty of Economics YSU Year of Study 2015-2017

\begin{tabular}{|c|c|c|}
\hline No & Year of Study & Amount \\
\hline 1 & 2015 & 71 students \\
\hline 2 & 2016 & 83 students \\
\hline 3 & 2017 & 67 students \\
\hline \multicolumn{2}{|c|}{ Total } & 221 students \\
\hline
\end{tabular}

Source: primary data

According to Arikunto (2014: 174), the sample is part or representative of the population to be studied. Named sample research if we intend to generalize the results of research samples. This study uses simple random sampling. In determining the number of samples of this study using a tolerance limit of $5 \%$ then the required sample is 142 students. Here is a sample of each year of study.

Table 2. Distribution of Number of Research Sample

\begin{tabular}{|c|c|c|c|}
\hline No & $\begin{array}{c}\text { Year of } \\
\text { Study }\end{array}$ & Amount & Sample \\
\hline 1 & 2015 & 71 & $\frac{71}{221} \times 142=46$ \\
\hline 2 & 2016 & 83 & $\frac{83}{221} \times 142=53$ \\
\hline 3 & 2017 & 67 & $\frac{67}{221} \times 142=43$ \\
\hline \multicolumn{2}{|c|}{ Total } & 221 & 142 \\
\hline
\end{tabular}

Sumber: primary data processed

\section{Data, Instrument, and Data Analysis Techniques}

1. Data Analysis Techniques

Data collection techniques used in this study was questionnaire. A questionnaire is a technique of data collection conducted by giving a set of questions or written statement to the respondent to answer (Sugiyono, 2015: 199). In this study, the data collected is The Level of Financial Literacy and Factors Influencing the Level of Financial Literacy. Researchers choose questionnaires as a method to collect 
research data because the data taken is a fact. Questionnaires in this study form a closed questionnaire that is provided answers so that respondents can choose directly the answer. Questions in this questionnaire are 30 questions.

2. Data Analysis Technique

The data analysis technique used in this study is using Ordinal Logistic Regression Analysis. In ordinal logistic regression analysis does not require that the normal distribution multivariate assumptions be met and does not require classical assumptions (Ghozali, 2013: 325). Logistic regression analysis is generally the same as linear regression, it is just that the dependent variable used is a non-metric or dummy variable. Following are ordinal logistic regression analysis models:

$$
\begin{gathered}
\operatorname{Ln}\left(\frac{P 1}{1-P 1}\right)=\alpha+\beta 1 \mathrm{X} 1+\beta 2 \mathrm{X} 2+\beta 3 \mathrm{X} 3+ \\
\beta 4 \mathrm{X} 4+\beta 5 \mathrm{X} 5+\beta 6 \mathrm{X} 6+\beta 7 \mathrm{X} 7+ \\
\beta 8 \mathrm{X} 8+\mu \\
\operatorname{Ln}\left(\frac{P 1+P 2}{1-P 1-P 2}\right)=\alpha+\beta 1 \mathrm{X} 1+\beta 2 \mathrm{X} 2+ \\
\beta 3 \mathrm{X} 3+\beta 4 \mathrm{X} 4+\beta 5 \mathrm{X} 5+\beta 6 \mathrm{X} 6+ \\
\beta 7 \mathrm{X} 7+\beta 8 \mathrm{X} 8+\mu \\
\operatorname{Ln}\left(\frac{P 1+P 2+P 3}{1-P 1-P 2-P 3}\right)=\alpha+\beta 1 \mathrm{X} 1+\beta 2 \mathrm{X} 2+ \\
\beta 3 \mathrm{X} 3+\beta 4 \mathrm{X} 4+\beta 5 \mathrm{X} 5+\beta 6 \mathrm{X} 6+ \\
\beta 7 \mathrm{X} 7+\beta 8 \mathrm{X} 8+\mu
\end{gathered}
$$

Informations:

$\mathrm{p} \quad$ : The Level of Financial Literacy

(P1, Low Level of Financial Literacy; P2, Medium Level of Financial Literacy; and P3, High Level of Financial Literacy)

$\alpha \quad$ : Constants

$\beta \quad$ : Coefficient of independent variable

X1 : Gender

$\mathrm{X} 2$ : GPA

X3 : Year of Study

X4 : Residence

X5 : Parent's Education Level (Father)

X6 : Parent's Education Level (Mother)

X7 : Parent's Income Level

X8 : Work Experience

\section{RESULT AND DISCUSSION \\ Model Feasibility Test (Goodness of Fit)}

The feasibility test of the model is conducted to see whether the empirical data is suitable or the resulting model is feasible to use and can predict the value of its observations. The test was done by Deviance test and Pearson test. Here is the hypothesis for the model feasibility test.

$\mathrm{H}_{0}$ : The hypothesized model feasible for use $\mathrm{H}_{1}$ : The hypothesized model not feasible for use

By using $\alpha=0,05$, the null hypothesis will be rejected when $p$-value $<0.05$. Failure to reject $\mathrm{H} 0$ means that the model is feasible to use and can predict its observation value or if the value is Sig. > 0.05 (Norusis, 2010: 78). The results of the model feasibility test in this study are as follows:

Table 3. Model Feasibility Test Results

\begin{tabular}{|l|c|c|c|}
\hline & $\begin{array}{c}\text { Chi- } \\
\text { Square }\end{array}$ & Df & Sig. \\
\hline Pearson & 156,082 & 203 &, 994 \\
Deviance & 138,860 & 203 & 1,000 \\
\hline
\end{tabular}

Source: primary data processed

The results of this test show chi-square (Pearson) and chi-square (Deviance) values. The chi-square (Pearson) value was 156,082 and the chi-square (Deviance) value was 138,860. As for the significance values of chi-square (Pearson) and chi-square (Deviance) are 0,994 and 1,000 with a significance value greater than 0,05 or fail to reject $\mathrm{H}_{0}$. This means that the model produced is in accordance with empirical data or is feasible to use and can predict the value of its observations.

\section{Model Accuracy Test (Model Fitting Information)}

This test is conducted to assess the overall fit model of the data. This test explains whether entering an independent variable in the model will contribute to the 
model. The hypothesis used for the overall test of this model is:

$\mathrm{HO}$ : The hypothesized model is fit with data H1 : The hypothesized model is not fit with data

This test was done by comparing the value of the initial -2 Likelihood Log (intercept only) with the -2Likelihood Log value in the final model. The decrease in the initial -2Likelihood Log value with the 2Log Likelihood final model shows that H0 cannot be rejected or the model is fit with the data (Ghazali, 2013: 332). The results of the model accuracy test in this study are as follows:

Table 4. Model Accuracy Test Results

\begin{tabular}{|l|c|c|c|c|}
\hline \multicolumn{1}{|c|}{ Model } & $\begin{array}{c}-2 \text { Log } \\
\text { Likelihood }\end{array}$ & $\begin{array}{c}\text { Chi- } \\
\text { Square }\end{array}$ & Df & Sig. \\
\hline $\begin{array}{l}\text { Intercept } \\
\text { Only }\end{array}$ & 191,848 & & & \\
Final & 158,268 & 33,580 & 9 &, 000 \\
\hline
\end{tabular}

Source: primary data processed

Based on the table above, it is known that the value of the initial -2 Likelihood Log (intercept only) without entering the independent variable was 191,848 . But by including the independent variable into the final model, the Likelihood Log value decreases to 158,268 . Change in value means that the model with independent variables is better than only the model with intercept. Thus, $\mathrm{H}_{0}$ cannot be rejected or it can be said that the model is fit with the data.

\section{Coefficient of Determination}

The coefficient of determination is used to determine the variability of the dependent variable which can be explained by the independent variable. The test results are as follows:

\section{Table 5. Coefficient of Determination} Results

\begin{tabular}{|l|c|}
\hline Cox and Snell &, 392 \\
\hline Nagelkerke &, 451 \\
\hline McFadden &, 245 \\
\hline
\end{tabular}

Source: primary data processed
The test results above show the Pseudo R-Square value. The Cox and Snell, Negelkerke and McFadden tests severally showed a coefficient of determination of $0,392(39,2 \%), 0,451(45,1 \%)$, and 0,245 $(24,5 \%)$. In ordinal logistic regression using McFadden to estimate R Square (Ghazali, 2013: 337). Based on the table above, it can be seen that McFadden's value is $24.5 \%$. This value indicates that the variability of the dependent variable can be explained by an independent variable of $24.5 \%$ and the remaining $75.5 \%$ is explained by independent variables outside the research model.

\section{Parallel Lines Test}

The parallel lines test assesses whether the assumption that all categories have the same parameters or not. A good model is a model that has the same parameters between the variables in the model. The following is a hypothesis for testing parallel lines.

HO : The resulting model has the same parameters

H1 : The resulting model has parameters which are not the same

In the parallel lines test the model is said to have the same parameters if it shows the value of Sig. $>0.05$ or fail to reject $\mathrm{H}_{0}$ (Ghozali, 2011: 363). The results of the parallel lines test of this study are as follows:

Table 6. Parallel Lines Test Results

\begin{tabular}{|c|c|c|c|c|}
\hline Model & $\begin{array}{c}-2 \text { Log } \\
\text { Likelih } \\
\text { ood }\end{array}$ & $\begin{array}{l}\text { Chi- } \\
\text { Square }\end{array}$ & Df & Sig. \\
\hline $\begin{array}{l}\text { Null } \\
\text { Hypothe } \\
\text { sis } \\
\text { General }\end{array}$ & $\begin{array}{r}158,268 \\
157,192\end{array}$ & 1,076 & 9 & ,999 \\
\hline
\end{tabular}

Source: primary data processed

Based on the table above, the resulting chi-square value is 1,076 with a significance of 0,999 . The calculation technique or option link used is the link function logit. This shows that the significance value obtained is 0,924 which is greater than 0,05 , the 
resulting model has the same parameters or fails to reject $\mathrm{H}_{0}$ and the selection of the model link function logit is correct.

\section{Hypothesis Test}

The hypothesis test in this ordinal logistic regression method uses the Regression Coefficient Test with the Wald Test. The Wald test is equivalent to the $t$ test. This test is performed to determine the influence of the independent variable on the dependent variable by assuming that the independent variable is constant. The hypothesis used in the regression coefficient test is as follows.

$\mathrm{H}_{0}: \beta \mathrm{i}=0$ (the independent variable does not influence the dependent variable)

$\mathrm{H}_{1}: \beta \mathrm{i} \neq 0$ (the independent variable influences the dependent variable)

If the value is Sig. $<0,05$ then $\mathrm{H}_{0}$ is rejected or it can be said that the independent variable has an influence on the dependent variable (Norusis, 2010: 80-81). The regression coefficient test results (Wald test) are as follows:

Table 7. Regression Coefficient Test Results

\begin{tabular}{|ll|c|c|c|c|c|}
\hline & & $\begin{array}{c}\text { Esti } \\
\text { mate }\end{array}$ & $\begin{array}{c}\text { Std. } \\
\text { Error }\end{array}$ & Wald & df & Sig. \\
\hline $\begin{array}{l}\text { Thresh } \\
\text { old }\end{array}$ & $\begin{array}{l}\text { [Liter } \\
\text { asi = }\end{array}$ & 1,880 & 1,642 & 1,312 & 1 &, 252 \\
& $\begin{array}{l}\text { 1] } \\
\text { [Liter } \\
\text { asi = }\end{array}$ & 6,142 & 1,752 & $\begin{array}{c}12,22 \\
7\end{array}$ & 1 &, 000 \\
& 2] & & & & & \\
Locati & & & & \\
on & X1 &,- 808 &, 537 & 2,269 & 1 &, 132 \\
& X2 & 1,484 &, 489 & 9,228 & 1 &, 002 \\
& X3 &, 826 &, 248 & 11,13 & 1 &, 001 \\
& X4 &,- 574 &, 398 & 2,084 & 1 &, 149 \\
& X5 &,- 067 &, 324 &, 043 & 1 &, 835 \\
& X6 &, 710 &, 336 & 4,466 & 1 &, 035 \\
& X7 &, 026 &, 194 &, 018 & 1 &, 894 \\
X8 & 1,259 &, 442 & 8,135 & 1 &, 004 \\
\hline
\end{tabular}

Source: primary data processed

Based on the table above, it is known that the variables $\mathrm{X} 2, \mathrm{X} 3, \mathrm{X} 6$, and $\mathrm{X} 8$ have the Sig. $<0,05$ then H0 is rejected for these variables. While variables $\mathrm{X} 1, \mathrm{X} 4, \mathrm{X} 5$, and $\mathrm{X} 7$ are known as Sig. > 0,05 so fail to reject $\mathrm{H} 0$ for these variables. The independent variables that influence the dependent variable are the GPA, Year of Study, Parent's Education Level (Mother), and Work Experience.

The table above also explains that there are three possible values of the Level of Financial Literacy (Y), namely:

$\mathrm{Y} 1=1$, Low if $\mathrm{Y} \leq 1,880$

$\mathrm{Y} 2=2$, Medium if $1,880<\mathrm{Y}<6,142$

$\mathrm{Y} 3=3$, High if $\mathrm{Y} \geq 6,142$

The ordinal logistic regression models of this study is as follows:

$$
\begin{gathered}
\operatorname{Ln}\left(\frac{P 1}{1-P 1}\right)=1,880-0,808 \mathrm{X} 1+1,484 \mathrm{X} 2+ \\
0,826 \mathrm{X} 3-0,574 \mathrm{X} 4-0,067 \mathrm{X} 5+ \\
0,710 \mathrm{X} 6+0,026 \mathrm{X} 7+1,259 \mathrm{X} 8
\end{gathered}
$$

$$
\begin{array}{r}
\operatorname{Ln}\left(\frac{P 1+P 2}{1-P 1-P 2}\right)=6,142-0,808 \mathrm{X} 1+1,484 \mathrm{X} 2 \\
+0,826 \mathrm{X} 3-0,574 \mathrm{X} 4-0,067 \mathrm{X} 5 \\
+0,710 \mathrm{X} 6+0,026 \mathrm{X} 7+1,259 \mathrm{X} 8
\end{array}
$$

Informations:

p1 : Low Level of Financial Literacy

p2 : Medium Level of Financial Literacy

X1 : Gender Variable

X2 : GPA Variable

X3 : Year of Study Variable

X4 : Residence Variable

X5 : Parent's Education Level Variable (Father)

X6 : Parent's Education Level Variable (Mother)

X7 : Parent's Income Level Variable

X8 : Work Experience Variable

\section{Discussion}

1. The Influence of Gender (X1) on the Level of Financial Literacy Students of Accounting Education Faculty of Economics YSU 2015-2017 (Y)

The first hypothesis states that Gender has an influence on the Level of Financial Literacy Students of Accounting Education Faculty of Economics YSU 2015-2017. Based on 
Table 7 above it is known that the regression coefficient of Gender variable is -0.808 with the value Sig. of 0,132 . The value of significance is greater than 0,05 so that Gender has not influence on the Level of Financial Literacy. The results of the study that were not significant explained that each student both male and female had the same opportunity to obtain good financial literacy. The results of this study are consistent with the research conducted by Nidar and Bestari (2012) and Shaari, et al. (2013) which states that gender does not affect financial literacy.

Rohmah (2014) states that gender equality proves there is no discrimination between men and women where they have the right to participate in carrying out their roles as human beings in social, economic, political and educational activities. This happens because in this modern era gender equality is part of the development of the times so that gender does not have an influence on the level of financial literacy. This statement is also supported by Shaari, et al. (2013) that now both men and women obtain the same education and also taught there is no difference.

2. The Influence of GPA (X2) on the Level of Financial Literacy Students of Accounting Education Faculty of Economics YSU 2015-2017 (Y)

The second hypothesis states that Grade Point Average (GPA) has an influence on the Level of Financial Literacy Students of Accounting Education Faculty of Economics YSU 2015-2017. Based on Table 7 above it is known that the regression coefficient of Gender variable is 1,484 with the value Sig. of 0,002 . The value of significance is less than 0,05 so that GPA has an influence on the Level of Financial
Literacy. The positive regression coefficient value indicates the positive effect of GPA on the Level of Financial Literacy.

Based on the results of the study, it is known that students who have a higher GPA will also have a higher level of financial literacy. The highest percentage of financial literacy or maximum score obtained by respondents is $83.33 \%$ with 25 correct answers from 30 questions. This highest score is obtained by students with a GPA With Compliments category $(3,51$ - 4,00). While the lowest percentage of financial literacy rate or minimum score obtained by respondents is $40.00 \%$ with 12 correct answers from 30 questions. This lowest score is obtained by students with a GPA Satisfactory category $(2,50-3,00)$. In addition, the average percentage of Satisfactory category (2.50 - 3.00) was $55.09 \%$, Very Satisfactory category $(3,01-3,50)$ was $60.67 \%$, and categories With Compliments $(3,51-4,00)$ was $61.81 \%$.

The results of this study were supported by Jinsoo, Kyungho, and Joon (2013) who stated that Grade Point Average (GPA) had a positive influence on financial literacy. Cude, et al. (2006), Margaretha and Pambudhi (2015), and Nababan and Sadalia (2012) states that students who have a higher GPA will have healthier finances compared to students who have a low GPA. This is because students who have a higher GPA will have a high level of intelligence and extensive knowledge and have a positive impact on the level of financial literacy. Students who get high scores on subjects related to finance also tend to have a higher level of financial literacy than students who get low scores (Wardani, Susilaningsih, \& Sangka, 2017). 
3. The Influence of Year of Study (X3) on the Level of Financial Literacy Students of Accounting Education Faculty of Economics YSU 2015-2017 (Y)

The third hypothesis states that Year of Study has an influence on the Level of Financial Literacy Students of Accounting Education Faculty of Economics YSU 2015-2017. Based on Table 7 above it is known that the regression coefficient of Year of Study variable is 0,826 with the value Sig. of 0,001 . The value of significance is less than 0,05 so that Year of Study has an influence on the Level of Financial Literacy. The positive regression coefficient value indicates the positive effect of Year of Study on the Level of Financial Literacy.

Based on the results of the study it is known that students who are more senior or take longer studies will have a higher level of financial literacy. The highest percentage of financial literacy or maximum score obtained by respondents is $83.33 \%$ with 25 correct answers from 30 questions. This highest score is obtained by students in year of study 2015. While the lowest percentage of financial literacy level or minimum score obtained by respondents is $40.00 \%$ with 12 correct answers from 30 questions. This lowest score is obtained by students in year of study 2017. In addition, the average percentage of students in the year of study 2017 was $58.99 \%$, the year of study 2016 students was $60.44 \%$, and the year of study 2015 students was $63.56 \%$.

The results of this study are supported by Cude, et al. (2006) and Shaari, et al. (2013) which states that year of study influences financial literacy. Students who study longer or senior students tend to have a higher level of financial literacy than junior students. More senior students have more life experience with financial products and the development of good financial behavior patterns (Mandell \& Klein, 2009). Older college student or senior student will have a better experience on financial literacy which acquired through courses, seminars, or through personal experience and mistakes that they are making on financial management (Chen \& Volpe, 1998: 116).

4. The Influence of Residence (X4) on the Level of Financial Literacy Students of Accounting Education Faculty of Economics YSU 2015-2017 (Y)

The fourth hypothesis states that Residence has an influence on the Level of Financial Literacy Students of Accounting Education Faculty of Economics YSU 2015-2017. Based on Table 7 above it is known that the regression coefficient of Residence variable is -0.574 with the value Sig. of 0,149 . The value of significance is greater than 0,05 so that Residence has not influence on the Level of Financial Literacy. The results of the study that did not significantly explain that every student who living alone (kost/boarding/dormitory) and living together with parent/guardian has not influence their level of financial literacy. The results of this study are consistent with the research conducted by Budiman (2017) and Nidar and Bestari (2012) which state that residence have no influence on financial literacy.

According to Margaretha and Pambudhi (2015) residence does not influence student financial literacy. In general, students either living alone (kost/boarding/dormitory) and living with parent/guardian do not have income and are still dependent on parents so that they cannot manage finances properly and this causes the 
residence to have no influence on financial literacy. However, the results of this study are not consistent with the research conducted by Nababan and Sadalia (2012) and Wardani, Susilaningsih, and Sangka (2017) which state that residence influence financial literacy.

5. The Influence of Parent's Education Level (Father) (X5) on the Level of Financial Literacy Students of Accounting Education Faculty of Economics YSU 2015-2017 (Y)

The fifth hypothesis states that Parent's Education Level (Father) has an influence on the Level of Financial Literacy Students of Accounting Education Faculty of Economics YSU 2015-2017. Based on Table 7 above it is known that the regression coefficient of Parent's Education Level (Father) variable is -0.067 with the value Sig. of 0,835 . The value of significance is greater than 0,05 so that Parent's Education Level (Father) has not influence on the Level of Financial Literacy. The results of the study that did not significantly explain that every student who has a father with the last level of education is primary education (SD/MI - SMP/MTs), secondary education (SMA/MA and SMK/MAK), or tertiary education (diploma, bachelor, master, specialist, and doctor) has not influence the level of financial literacy. The results of this study are consistent with the research conducted by Nababan and Sadalia (2012) and Maulani (2016) which states that father's education level does not influence financial literacy.

In theory, parent especially father, with high levels of education tend to have extensive views and better abilities to obtain high income so that they can provide facilities for their children to save money and introduce bank products (Homan, 2015). But in this study father's education level has not influence financial literacy. This can be caused by several things. Although father has a high level of education but if they are unable to provide knowledge and direction regarding financial products to their children, their high education will not affect children's financial literacy. In addition, the high education of father does not express father's intelligence on financial concepts so that father's inability to provide the understanding of financial concepts to children may be limited. In the family, father acts as the head of the family who has the main task. One of the main tasks of the father is to make a living, with this condition father will give the task to educate the child to the mother. This shows that mothers are more instrumental in teaching children everything including teaching about financial management.

6. The Influence of Parent's Education Level (Mother) (X6) on the Level of Financial Literacy Students of Accounting Education Faculty of Economics YSU 2015-2017 (Y)

The sixth hypothesis states that Parent's Education Level (Mother) has an influence on the Level of Financial Literacy Students of Accounting Education Faculty of Economics YSU 2015-2017. Based on Table 7 above it is known that the regression coefficient of Parent's Education Level (Mother) variable is 0,710 with the value Sig. of 0,035 . The value of significance is less than 0,05 so that Parent's Education Level (Mother) has an influence on the Level of Financial Literacy. The positive regression coefficient value indicates the positive effect of Parent's Education Level (Mother) on the Level of Financial Literacy. 
Based on the results of the study, it is known that students who have a mother with a higher education level will also have a higher level of financial literacy. The highest percentage of financial literacy or maximum score obtained by respondents is $83.33 \%$ with 25 correct answers from 30 questions. This highest score is obtained by students who have mother with tertiary education (diploma, bachelor, master, specialist, and doctor). While the lowest percentage of financial literacy or minimum score obtained by respondents is $40.00 \%$ with 12 correct answers from 30 questions. This lowest score is obtained by students who have mothers with primary education (SD/MI - SMP/MTs). In addition, the average percentage of students who have mothers with primary education (SD/MI - SMP/MTs) was $57.75 \%$, secondary education (SMA/MA and SMK/MAK) was $60.96 \%$, and tertiary education (diploma, bachelor, master, specialist, and doctor) was $63.20 \%$.

The results of this study are supported by Wardani, Susilaningsih, and Sangka (2017) and Ansong and Gyensare (2012) which state that the education level of mother influences financial literacy. Mother has a role in the family to educate and teach children about basic concepts, one of which is the concept of managing personal finance. Lusardi, et al. (2014) stated that someone who plays an important role in providing information and education about financial problems in children is parents, especially mothers. Mother who has higher education tend to know various ways to manage finances well. The mother's knowledge is then channeled to their children. Mothers who are good at managing finances will implicate it in daily life in a family. The habits of mothers in managing finances will be an example for their children.
Children will learn financial concepts through good mother habits (Maulani, 2016).

7. The Influence of Parent's Income Level (X7) on the Level of Financial Literacy Students of Accounting Education Faculty of Economics YSU 2015-2017 (Y)

The seventh hypothesis states that Parent's Income Level has an influence on the Level of Financial Literacy Students of Accounting Education Faculty of Economics YSU 2015-2017. Based on Table 7 above it is known that the regression coefficient of Parent's Income Level variable is 0.026 with the value Sig. of 0,894 . The value of significance is greater than 0,05 so that Parent's Income Level has not influence on the Level of Financial Literacy. The results of the study that did not significantly explain that every student who has a parent with. low income class (average income IDR 1.500.000,00 per month), medium income class (average revenue between IDR 1.500.000,00 IDR 2.500.000,00 per month), high income class (average income between IDR 2.500.000,00 - IDR 3.500.000,00 per month), or very high income class (average income more than IDR 3.500.000,00 per month) has not influence the level of financial literacy. The results of this study are consistent with the research conducted by Nababan and Sadalia (2012) and Budiman (2017) which states that parent's income level does not influence financial literacy. This explains that students who have parent with low income class do not necessarily have a low level of financial literacy, but can actually motivate themselves to obtain high financial literacy.

8. The Influence of Work Experience (X8) on the Level of Financial Literacy 
Students of Accounting Education Faculty of Economics YSU 2015-2017 (Y)

The eighth hypothesis states that Work Experience has an influence on the Level of Financial Literacy Students of Accounting Education Faculty of Economics YSU 2015-2017. Based on Table 7 above it is known that the regression coefficient of Work Experience variable is 1,259 with the value Sig. of 0,004 . The value of significance is less than 0,05 so that Work Experience has an influence on the Level of Financial Literacy. The positive regression coefficient value indicates the positive effect of Work Experience on the Level of Financial Literacy.

Based on the results of the study, it is known that students who have work experience will have a higher level of financial literacy. The highest percentage of financial literacy or maximum score obtained by respondents is $83.33 \%$ with 25 correct answers from 30 questions. This highest score is obtained by students who having worked or have work experience. While the lowest percentage of financial literacy rate or minimum score obtained by respondents is $40.00 \%$ with 12 correct answers from 30 questions. This lowest score is obtained by students who have never worked or have no work experience. In addition, the average percentage of students who having worked or have work experience was $64.14 \%$ while students who have never worked or have no work experience was $59.91 \%$.

The results of this study are consistent with research conducted by Ansong and Gyensare (2012) and Chen and Volpe (1998) which state that work experience influences financial literacy. According to Krishna, Rofaida, and Sari (2010) students who have worked have better experiences in planning, managing, and making well-assembled decisions. Students who have high work experience will make wiser financial decisions than those without work experience. This happens because the more the intensity of a person is faced with financial issues, the higher his knowledge will be and the better the financial decisions will be made.

\section{CONCLUSION AND SUGGESTION Conclusion}

Based on the data obtained from the analysis, it can be concluded that:

1. Gender has not influence on the Level of Financial Literacy Students of Accounting Education Faculty of Economics YSU 2015-2017. Gender variable regression coefficient value of $-0,808$ with Sig. value of 0,132 exceeding the significance level of the study which is $5 \%$ or 0,05 .

2. GPA has a positive influence on the Level of Financial Literacy Students of Accounting Education Faculty of Economics YSU 2015-2017. GPA variable regression coefficient value of 1,484 with Sig. value of 0,002 below the significance level of the study which is $5 \%$ or 0,05 .

3. Year of Study has a positive influence on the Level of Financial Literacy Students of Accounting Education Faculty of Economics YSU 2015-2017. Year of Study variable regression coefficient value of 0,826 with Sig. value of 0,001 below the significance level of the study which is $5 \%$ or 0,05 .

4. Residence has not influence on the Level of Financial Literacy Students of Accounting Education Faculty of Economics YSU 2015-2017. Residence variable regression coefficient value of $-0,574$ with Sig. value of 0,149 exceeding the significance level of the study which is $5 \%$ or 0,05 . 
5. Parent's Education Level (Father) has not influence the Level of Financial Literacy Students of Accounting Education Faculty of Economics YSU 2015-2017. Parent's Education Level (Father) variable regression coefficient value of $-0,067$ with $\mathrm{Sig}$. value of 0,835 exceeding the significance level of the study which is $5 \%$ or 0,05 .

6. Parent's Education Level (Mother) has a positive influence on the Level of Financial Literacy Students of Accounting Education Faculty of Economics YSU 2015-2017. Parent's Education Level (Mother) variable regression coefficient value of 0,710 with Sig. value of 0,035 below the significance level of the study which is $5 \%$ or 0,05 .

7. Parent's Income Level has not influence the Level of Financial Literacy Students of Accounting Education Faculty of Economics YSU 2015-2017. Parent's Income Level variable regression coefficient value of 0,026 with Sig. value of 0,894 exceeding the significance level of the study which is $5 \%$ or 0,05 .

8. Work Experience has a positive influence on the Level of Financial Literacy Students of Accounting Education Faculty of Economics YSU 2015-2017. Work Experience variable regression coefficient value of 1,259 with Sig. value of 0,004 below the significance level of the study which is $5 \%$ or 0,05 .

\section{Suggestion}

Based on the results of the discussion and the conclusion above, the authors provide some suggestions as follows:

\section{For Students}

Students are advised to be more proactive and learn financial literacy indicators, especially in the banking sector (savings and loans), pension funds, and financial institutions which are still included in the low category in this research. In addition, it is also recommended to increase knowledge about other indicators that are included in the medium category such as knowledge of personal finance in general, insurance, capital markets (investment), and pawnshops. Students can also improve their knowledge about financial literacy by utilizing the Financial Literacy Series for College Students launched by Otoritas Jasa Keuangan.

Based on the results of the study, it is known that students with GPA Satisfactory categoriy $(2,50-3,00)$, students year of study 2017, students who have mother with primary education (SD/MI - SMP/MTs), students who have no work experience, and students who have father with tertiary education (diploma, bachelor, master, specialist, and doctor) of $57.58 \%$, students who have parents with very high income groups (average income is more than Rp. 3,500,000.00 per month), and students who have parent with medium income class (average income between IDR 1,500,000.00 - IDR 2,500,000.00 per month) have low financial literacy. The student should increase their knowledge about financial literacy. This can be done through lecture activities or by adding other sources of information about financial literacy.

2. For Faculty of Economics YSU

Faculty and teaching staff should provide additional information for students regarding knowledge about financial literacy and all its indicators during lecture activities or by holding seminars, public lectures or similar activities to improve student financial literacy.

3. For Further Researcher 
Based on McFadden's value of $24.5 \%$, it is known that the variability of the dependent variable can be explained by the independent variable was $24.5 \%$ and the remaining $75.5 \%$ was explained by independent variables outside the research model. Future researchers are expected to be able to conduct research with more varied variables.

The next researcher is expected to expand the population and sample so that the factors that most influence the level of financial literacy can be known. The next researcher is expected not only to use the research instrument in the form of questionnaires only so that the suitability between the respondent's answers to the real conditions of the respondents can be more controlled.

\section{REFERENCES}

Ansong, A., \& Gyensare, M. A. (2012). Determinants of University Working-Students' Financial Literacy at The University of Cape Coast, Ghana. International Journal of Business and Management, 7, 126-133.

Arikunto, S. (2014). Prosedur Penelitian Suatu Pendekatan Praktik. Jakarta: Rineka Cipta.

Budiman. (2017). Analisis Literasi Keuangan Mahasiswa Jurusan Ekonomi Syari'ah dan Faktor-Faktor yang Mempengaruhinya (Studi di Kabupaten Lebak). Tesis Magister: UIN Sultan Maulana Hasanuddin Banten.

Cahyaningsih, D. S. (2011). Pertumbuhan Perkembangan Anak dan Remaja. Jakarta: CV Trans Info Media.

Chen, H., \& Volpe, R. P. (1998). An Analysis of Personal Financial Literacy Among College Students.
Financial Services Review, 7, 107128.

Cude, B., Lawrence, F., Lyons, A., Metzger, K., LeJeune, E., Marks, L., \& Matchmes, K. (2006). College Students and Financial Literacy: What They Know and What We Neew to Learn. Eastern Family Economics and Resource Management Association, 102-109.

Darmadi, H. (2013). Metode Penelitian Pendidikan. Bandung: Alfabeta.

Ghozali, I. (2011). Aplikasi Analisis Multivariate dengan Program IBM SPSS 19. Semarang: Badan Penerbit Universitas Diponegoro.

Homan, H. S. (Mei 2015). Comparative Study of Student Financial Literacy and Its Demographic Factors. Makalah disajikan dalam Seminar First International Conference on Economics and Banking, di STIE Ekuitas Bandung.

Jinsoo, H., Kyungho, J., \& Joon, P. H. (2013). Financial Literacy of Korean High School Students.

Krishna, A., Rofaida, R., \& Sari, M. (November 2010). Analisis Tingkat Literasi Keuangan di Kalangan Mahasiswa dan Faktor-Faktor yang Mempengaruhinya (Survey pada Mahasiswa Universitas Pendidikan Indonesia). Makalah disajikan dalam Proceedings of The 4th International Conference on The Teacher Education, di Universitas Pendidikan Indonesia.

Lusardi, A., \& Mitchell, O. S. (2014). The Economic Importance of Financial Literacy: Theory and Evidence. 
Journal of Economic Literature, 52, 5-44.

Mandell, L., \& Klein, L. S. (2009). The Impact of Financial Literacy Education on Subsequent Financial Behaviour. Association for Financial Counseling and Planning Education, 20, 15-24.

Margaretha, F., \& Pambudhi, R. A. (2015). Tingkat Literasi Keuangan pada Mahasiswa S-1 Fakultas Ekonomi. Jurnal Manajemen dan Kewirausahaan, 17, 76-85.

Maulani, S. (2016). Analisis Faktor-Faktor yang Memengaruhi Literasi Keuangan (Studi pada Mahasiswa Jurusan Manajemen Fakultas Ekonomi Universitas Negeri Semarang Aktif Semester Genap Tahun 2015/2016). Skripsi: Universitas Negeri Semarang.

Nababan, D., \& Sadalia, I. (2012). Analisis Personal Financial Literacy dan Financial Behaviour Mahasiswa Strata 1 Fakultas Ekonomi Universitas Sumatera Utara. 1-16.

Nidar, S. R., \& Bestari, S. (2012). Personal Financial Literacy Among University Students and Analyze Factors that Influence It (Case Study at Padjadjaran University Students Bandung Indonesia). World Journal of Social Sciences, 2, 1-12.

Norusis, M. (2010). SPSS Advanced Statistical Procedures Companion. New York: Prentice Hall.

Rohmah, A. N. (2014). Perbedaan Financial Literacy Mahasiswa Pelaku Usaha di Fakultas Ekonomi Universitas Negeri Yogyakarta Berdasarkan Gender dan Kemampuan Kognitif.
Skripsi: Universitas Negeri Yogyakarta.

Shaari, N. A., Hasan, N. A., Mohamed, R. K., \& Sabri, M. A. (2013). Financial Literacy: A Study Among The University Student. Interdiciplinary Journal of Contemporary Research in Business, 5, 279-299.

Sugiyono. (2015). Metode Penelitian Pendidikan: Pendekatan Kuantitatif, Kualitatif dan $R \& D$. Bandung: Alfabeta.

Visa. (2012). Visa's International Financial Literacy. Foster City: Practical Money Skills for Life.

Wardani, E. W., Susilaningsih, \& Sangka, K. B. (2017). Faktor-Faktor yang Memengaruhi Literasi Keuangan Mahasiswa Program Studi Pendidikan Akuntansi Fakultas Keguruan dan Ilmu Pendidikan Universitas Sebelas Maret. Jurnal Tata Arta UNS, 3, 80-93. 